\title{
A Six Sigma Approach to Water Savings
}

\author{
Ryland Cairns (Corresponding author) \\ Fontus Environmental, Thirsk, North Yorkshire, England \\ Email: Ryland@fontusenvironmental.com
}

Michael MacPherson

Water Services Department, Interserve

Whale Way, Mount Pleasant Complex, Falkland Islands, FIQ 1ZZ

E-mail: Michael.macpherson@interserve.mod.uk

Received: March 20, 2017 Accepted: May 9, 2017

doi:10.5296/emsd.v6i2.10953 URL: https://doi.org/10.5296/emsd.v6i2.10953

\begin{abstract}
The purpose of this paper is to explore the potential of a six sigma approach to reducing water losses through a combination of water efficiency and leak detection on a private distribution system. The paper takes the form of a case study that investigates the implementation of water reduction strategy across an estate with 26 miles of potable water pipe and over 200 facilities. This incorporates methods developed in the water industry such as water loss reduction and water demand management. The paper demonstrates that large water savings could be made through adoption of a six sigma approach. The approach has the potential to be applied to a wide range of situations including sites with limited technology. This case study provides a useful source for Facilities Managers involved in the management of utilities to determine suitable water saving approaches and strategies for large estates with private water distribution networks.
\end{abstract}

Keywords: Water loss, Six sigma, Water efficiency, Water management, Private water supplies, Facilities management

\section{Introduction}

There is an increasing global awareness that water scarcity is one of the emerging issues of this century (Morais and Teixeira de Almeida, 2007). The demand for this precious commodity is continuingly escalating through increased population and changes in precipitation patterns brought on by climate change (Bates et al. 2008). Effective utilisation 
of water through the reduction of wastage either within distribution (leaks) or at the point of use (water inefficiency) remains a key problem for both developing and developed countries throughout the world (Morais and Teixeira de Almeida, 2007).

Leakage from water distribution systems has been a widely research topic due to the large percentage of losses encountered even on the smallest systems. Annually the global water sector processes 32 billion cubic meters of water that is lost through leaks (Kingdom et al., 2006) accounting for $9 \%-43 \%$ of the nations total production (Lai, 1991). In addition to the physical loss of water there are other deleterious impacts relating to energy consumption, chemical consumption potential health and environmental risks (Colombo et al., 2009) with an associated total financial of cost of US\$15.6 billion (Kingdom et al., 2006). One such issue is the energy consumption associated with treating and pumping leaked water (Colombo and Karney, 2002). This is thought to account for 5-10 billion $\mathrm{kWh}$ of power generated a year, in the states alone (AWWA, 2003). Water hygiene issues are also associated with burst or leaks through the intrusion of contaminated groundwater. Karim et al., (2003) demonstrated that a high percentage of soils and potentially harmful pathogenic organism such as coliforms (58\% and $70 \%$ of water and soil samples respectively) and faecal coliforms (detected in $43 \%$ and $50 \%$ of the water and soil samples respectively). During low pressure events on a burst line it is possible for these contaminants to be drawn in to the system.

Water demand management (WDM) deals with developing and implementing strategies aimed at influencing water demand by improving efficiency to reduce average water consumption (Brooks, 2006). WMD strategies focus on providing tools, mechanisms and knowledge to enable users to reduce water consumption. Such tools include high efficiency water fixtures and appliances that have demonstrated to support least cost planning strategies for water conservation and are thus a good starting point prior to high cost capital works (Stewart et al., 2010). The provision of knowledge aims to influence attitudes and behaviours which can have a significant effect on water consumption (Willis et al., 2011).

An increased focus on sustainability performance from a range stakeholders has meant that companies must also adapt to support this new core activity (Price et al., 2011; Garza-Reyes, 2015). The built environment is responsible for half of the UK's water consumption (BIFM, 2007) thus sustainability targets are likely to include water usage. It has been reported that UK private sector could realise savings in excess of $£ 3.5$ billion a year through the adoption of water efficient practices (Environment Agency, 2012). These practices are also being brought in to the Public Sector through the introduction of the Greening Government Commitments. This has seen the Ministry of Defence (MOD) introduce water reduction targets as part of the new regional prime contracts (FM World, 2013).

To reduce the likelihood of failure the utilisation of frameworks to support improvement initiatives is deemed critical (Oakland and Tanner, 2007). One such framework is Six Sigma which has gained recognition as a quality improvement methodology within the manufacturing and service industries (Basu, 2004). It has been applied successfully to the utilities industry (Inozu et al., 2006; Pheng and Hui, 2004) and can be used to drive sustainability initiatives (Zhang and Awasthi, 2014; Banawi and Bilec, 2014; Cherrafi et al., 


\section{Macrothink}

2016a; Cherrafi et al., 2016b). Although other frameworks, such as lean, have been proposed to improve sustainability performance it is believed that their integration has not assisted organisations achieve peak performance, unlike that of Six Sigma (Banawi and Bilec, 2014).

This case study investigates a water saving strategy implemented within an MOD estate on the Falkland Islands using a six sigma approach.

\section{Case Study}

\subsection{RAF Mount Pleasant Complex}

Mount Pleasant Complex (MPC) is operational British Military theatre situated in the Falkland Islands with a primary mission statement to deter and defend against foreign aggressors. To enable the MOD to focus on their core activities infrastructure service provision, such as power generation and water production, is outsourced.

Water services cover all aspects of water and wastewater treatment. This involves the management of a treatment plant and distribution system in line with The Private Water Supply Regulations. The task inherently involves the metering of water consumption around the estate.

Following an increase in consumption over the years as well as the introduction of environmental targets there has been an increased emphasis on the management of leaks and water efficiency.

\subsection{Water Consumption}

Over the years, the activities and population of MPC have remained fairly constant. During this time, there has been a steady $27.13 \%$ increase in water consumption from $25,339 \mathrm{~m}^{3}$ in 2002 to $32,216 \mathrm{~m}^{3}$ in 2009 (figure 1). This has ranged from a mean consumption of $713 \mathrm{~m}^{3} /$ day in May 2003 to $1270 \mathrm{~m}^{3} /$ day in June 2009. Despite the repair of a major leak in July 2009, consumption continued to rise.

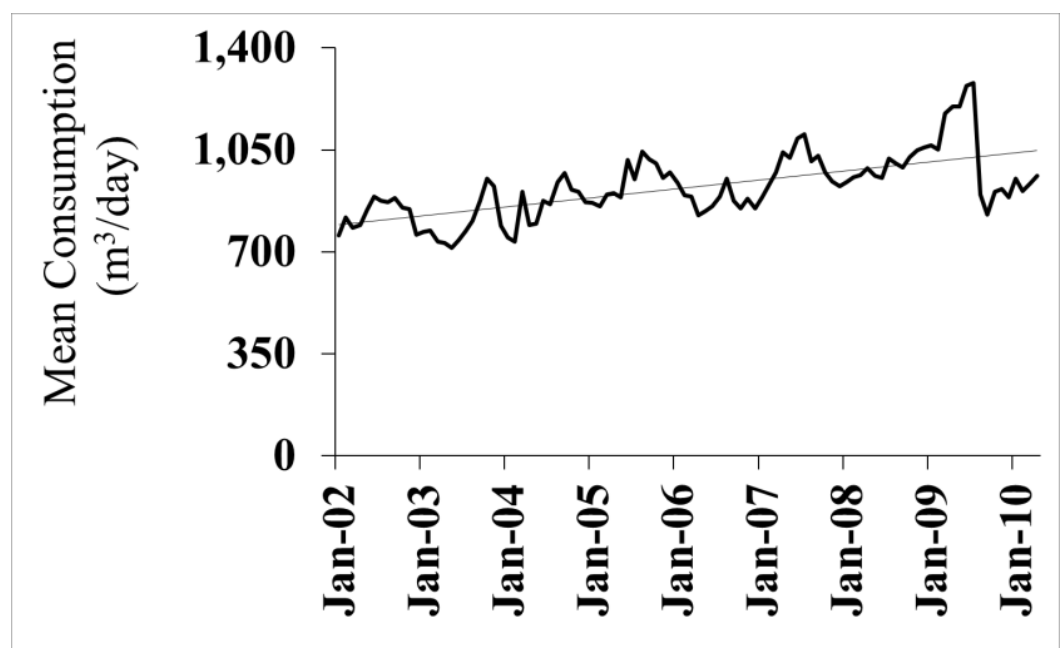

Figure 1. Site Consumption

Average domestic water consumption in the UK has been estimated at 1501/Person/day 
(Waterwise, 2012). On MPC total water consumption has ranged from 356-6351 per person per day from 2002 to 2009 , roughly two to four times in excess of that in the UK, however it should be noted that this includes non-domestic water which is used in centralised kitchens, boiler house operations and vehicle wash-down equipment. Due to metering arrangements it is not possible to differentiate between the two.

Under previous Environmental targets, the UK "Greening Government Commitments" the MoD has been set targets of reducing water consumption by $7 \%$ on the estate by 2016 relative to $2010 / 2011$ levels.

\section{Case Study}

"Six Sigma is an organized, parallel-meso structure to reduce variation in the organizational processes by using improvement specialists, a structured method, and performance metrics with the aim of achieving strategic objectives" (Schroeder et al., 2008). Using a data driven improvement methodology Six Sigma aims to identify and significantly reduce operational defects and variability to improve process performance ( $\mathrm{Zu}$ et al., 2008; Laureani et al., 2009). The six sigma methodology that was used to guide implementation was the five phase DMAIC cycle (define, measure, analyse, improve and control) (Bergman and Klefsjo, 2003) whereby the initial problem is defined prior to the utilisation of various tools to measure, analyse and seek the root causes which can be removed and controlled to ensure performance (Cherrafi et al., 2016a).

In this case study the process problem which was being addressed was water loss and water inefficiencies. Six Sigma tools were used alongside standard water industry approaches to aid with the measurements and analysis.

\subsection{Define}

The charter of the six sigma project was developed by the Water Services Manager. The business case was based on the fact that water demand was on the verge of exceeding supply across MPC, despite efforts to optimise water processes to maximise the inputs (Cairns et al., 2012). The situation had led to excessive chemical consumption, increased pumping costs and a twofold increase in operator overtime. Due to the age of the infrastructure, water demand was likely to be excessive as a result of large leaks and inefficient water fittings.

The process improvement tool SIPOC; suppliers, inputs, process, outputs, and customers (Table 1) was used to define the system to allow for better targeting of resources. The SIPOC revealed that the process of water delivery could be split into three distinct levels within the system (main feed, distribution and facilities). This identified that the main goal of reducing overall water consumption could be achieved through a combination of leak reduction techniques on the main distribution system and a water demand management approach within the facilities. 


\section{Macrothink}

Table 1. SIPOC of water delivery

\begin{tabular}{|c|c|c|c|c|}
\hline Suppliers & Inputs & Processes & Outputs & Customer \\
\hline Water & Potable & Pumping of water & Supplied & MPC \\
Services & Water & Main feed $\rightarrow$ distribution $\rightarrow$ facilities & Water & inhabitants \\
\hline
\end{tabular}

\subsection{Measure}

An array of measurement techniques were formulated to cover each of these separate areas and provide a holistic picture of water consumption, losses and inefficiencies, taking into account the limited technology onsite (Figure 2).

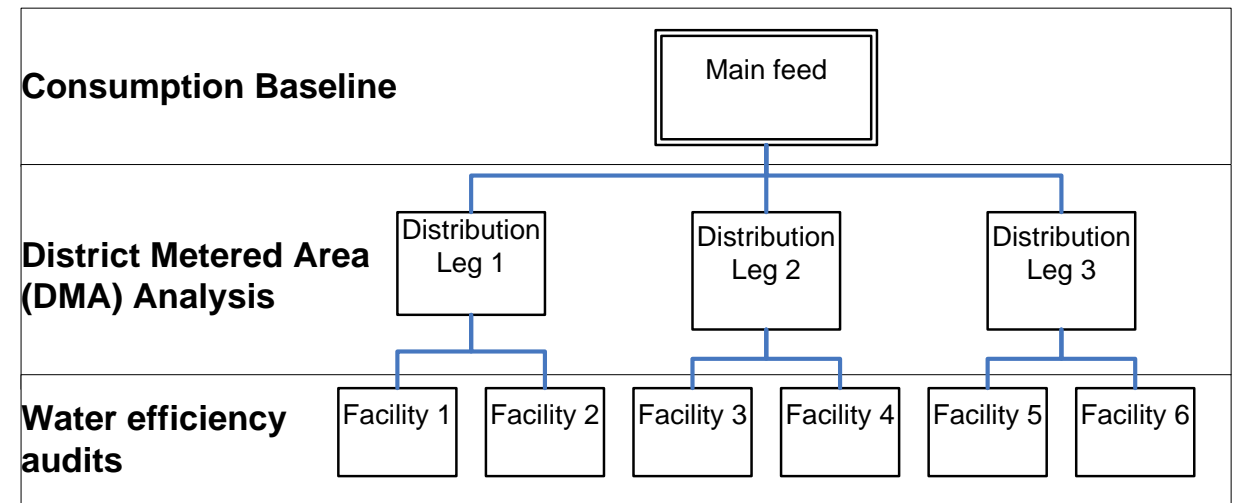

Figure 2. Measurement techniques at various levels of the distribution system

The first stage of the measurement process involved determining the base line consumption figures for the site on a day-to-day basis. This included overall consumption for the site (Figure 1) and minimum night flow (MNF). MNF measurements provide a better indication of leakage on the system compared to daily readings since actual demand is at its lowest during night time $(0100 \mathrm{hrs}-0300 \mathrm{hrs})$ making the leakage component the highest percentage of flow (Morrison, 2004).

The second stage of the measuring process involved the setting up and monitoring of District Metered Areas (DMAs). A DMA is specifically defined area of a distribution system in which the quantities of water entering and leaving the district can be metered. Flow monitoring (particularly MNF) can be used to calculate the level of leakage within a district providing an indication of levels of leakage within different areas and where resources should be focused (Morrison, 2004)

Flow measurements from the final meters on the DMAs provided an indication of consumption within individual facilities and could be fed in to the final stage Water Efficiency Audit. The audit used a standardised form to determine if actual consumption was inline with expected consumption based on staffing levels and fittings within the facility (Affinity Water, 2010). Analysis of night time readings supported this by providing an indication of leaks within individual facilities. 


\section{Macrothink}

\subsection{Analyse}

Results from the DMA analysis illustrated that the high site consumption was the result of one particularly problematic distribution leg comprising 4 DMAs.

DMA analysis of this leg (Table 2) showed that $77.28 \%$ of the total water was lost to leakage, accounting for $23 \%$ of total consumption for the site. The worst areas were DMA 2 and DMA 4 which lost roughly $188 \mathrm{~m}^{3}$ and $24 \mathrm{~m}^{3}$ a day respectively. DMA 3 and 1 experienced comparatively lower calculated losses at $1 \mathrm{~m}^{3}$ and $2 \mathrm{~m}^{3}$ respectively.

Table 2. DMA analysis based off mean daily consumption figures (January 2010)

\begin{tabular}{|l|c|c|c|c|}
\hline & Expected Consumption (L) & Actual (L) & Losses (L) & Losses (\%) \\
\hline DMA 1 & 278,137 & 276,616 & 1,521 & 0.55 \\
\hline DMA 2 & 263,742 & 75,256 & 188,486 & 71.47 \\
\hline DMA 3 & 14,484 & 13,419 & 1,065 & 7.35 \\
\hline DMA 4 & 58,484 & 34,602 & 23,882 & 40.83 \\
\hline & & Total & 214,954 & $77.28 \%$ \\
\hline
\end{tabular}

In addition to the high percentage of water loss through leaks on this leg the water efficiency audits revealed that a number of metered facilities experienced excessive consumption (Table 3) totalling $10 \mathrm{a} \mathrm{m}^{3}$ day between 2-3. In all cases, there was significant flow (up to 150 litres hour) during the periods of $0100-0300 \mathrm{hrs}$. Water efficiency audits revealed that it was a faulty urinal flow control devices at the facilities with meters 1, 37 and 40, whilst an external water leak was the cause of high water consumption at meter 6 .

Table 3. Water Efficiency Analysis (August 2010)

\begin{tabular}{|c|c|c|c|r|}
\hline & $\begin{array}{c}\text { Expected daily Consumption } \\
(\mathrm{L})\end{array}$ & $\begin{array}{c}\text { Mean daily consumption } \\
(\mathrm{L})\end{array}$ & $\begin{array}{c}\text { Water consumption per } \\
\text { person per day (L) }\end{array}$ & $\begin{array}{c}\text { Potential } \\
\text { Losses }\end{array}$ \\
\hline Meter 1 & 1,600 & 4,635 & 144 & 3,035 \\
\hline Meter 6 & 400 & 3,130 & 98 & 2,730 \\
\hline Meter 37 & 1,600 & 3,625 & 113 & 2,025 \\
\hline Meter 40 & 500 & 2,833 & 88 & 2,333 \\
\hline
\end{tabular}

\subsection{Improve}

Corrective action was prioritised as per (Figure 3). Leaks were located using a combination of visual inspections of the lines, and valve pits in dry conditions and step analysis. Faulty urinal flow monitors were corrected, monitored and replaced if broken. In terms of DMA analysis (Table 4) this lead to a $251 \mathrm{~m}^{3}$ reduction in consumption along the leg and a drop in the water losses from $77.28 \%$ to $17.01 \%$. The greatest improvements were realised following work to DMA 2 and DMA 4. 


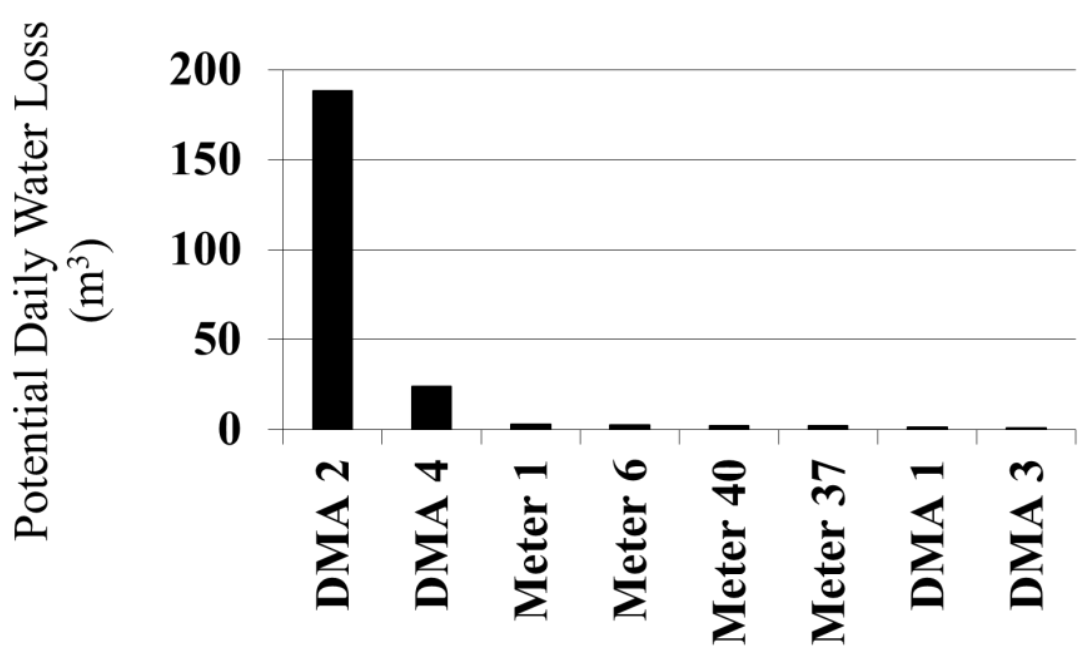

Figure 3. Work Prioritisation based off potential water losses

Table 4. DMA analysis December 2011

\begin{tabular}{|l|c|c|c|c|}
\hline & Expected Consumption (L) & Actual (L) & Losses (L) & Losses (\%) \\
\hline DMA 1 & 28354 & 25442 & 2912 & 10.27 \\
\hline DMA 2 & 13491 & 11962 & 1529 & 11.33 \\
\hline DMA 3 & 6419 & 6190 & 229 & 3.57 \\
\hline DMA 4 & 3897 & 3743 & 154 & 3.95 \\
\hline & & Total & 4,824 & $17.01 \%$ \\
\hline
\end{tabular}

Following repairs to the main potable line, building water efficiency was targeted. Night time meter readings revealed either leaks meter side of the building or inefficient water fittings the most common fault was with urinal control devices. These were adjusted where possible and replaced leading to large water efficiency savings within buildings (table 5).

Table 5. Water Efficiency Analysis December 2011

\begin{tabular}{|c|c|c|c|}
\hline & $\begin{array}{c}\text { Mean daily consumption } \\
\text { End (L) }\end{array}$ & $\begin{array}{c}\text { Water consumption per } \\
\text { person per day (L) }\end{array}$ & $\begin{array}{c}\text { Daily Water Saving } \\
(\mathrm{L})\end{array}$ \\
\hline Meter 1 & 352 & 11 & 4,283 \\
\hline Meter 6 & 194 & 24 & 2,936 \\
\hline Meter 37 & 625 & 20 & 3,000 \\
\hline Meter 40 & 192 & 19 & 2,641 \\
\hline
\end{tabular}

From the start of the trials in April 2010 there was a 39\% decrease in mean monthly water consumption from $962 \mathrm{~m}^{3} /$ day to $584 \mathrm{~m}^{3} /$ day in July 2014 (Fig 4). Over the course of a year, this would have provided a saving of 137 million litres. A $39.3 \%$ reduction in annual consumption from 2009 compared to 2014 (Fig 5) led to the lowest consumption figures on record and the internal water efficiency targets for 2020. 


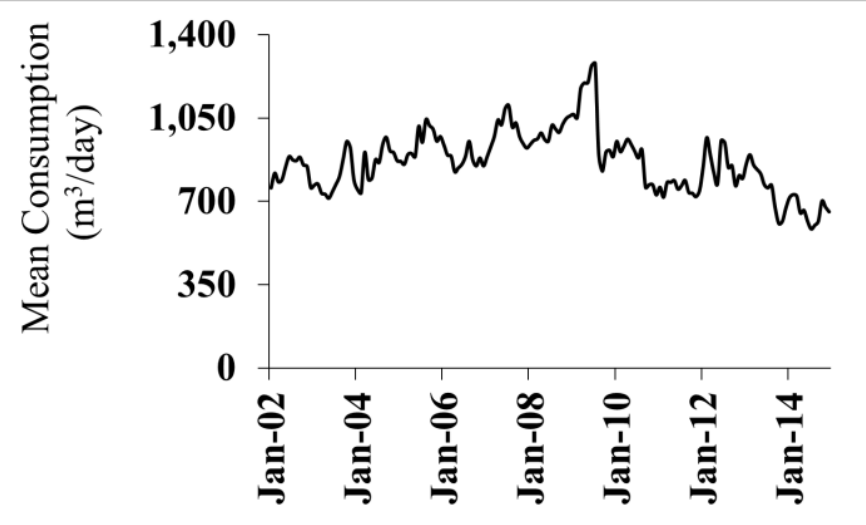

Figure 4. Mean Daily Consumption

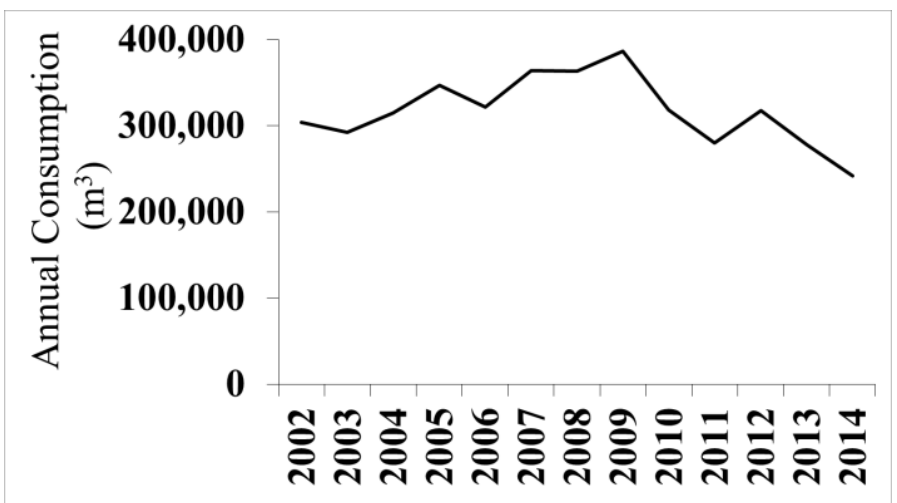

Figure 5. Annual Consumption

\subsection{Control}

Minimum night flow was used as the main control measurement (Fig 6). Investigations were initiated in the instances where water consumption rose above $22.5 \mathrm{~m}^{3} / \mathrm{h}$ in the form of further DMA analysis and water efficiency audits around MPC. Following the initial investigations which realised issues with the urinal control systems water efficiency training was provided to cleaning staff. This proved a successful control measure which helped identify several faulty urinals and leaks.

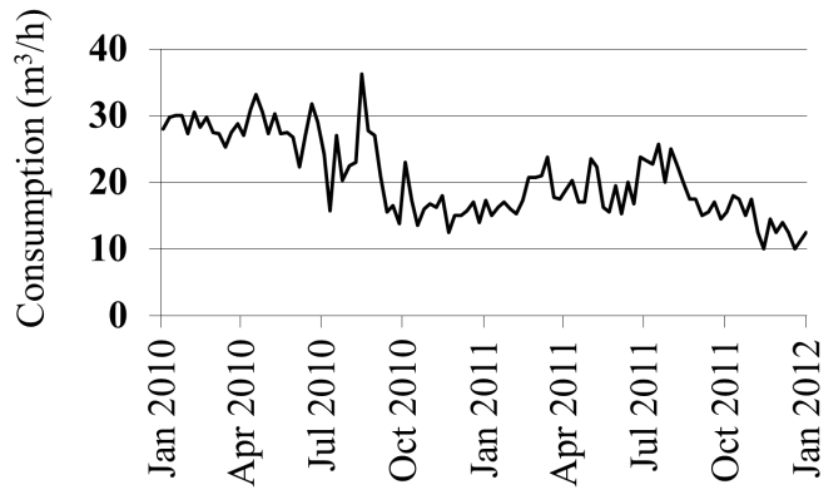

Figure 6. Minimum Night Flow 


\section{Discussion}

The successful application of water management tools utilising a six sigma approach further strengthens the notion that Six Sigma is not just applicable to manufacturing operations (Anthony, 2007; Laureani et al., 2009). The systematic approach of this methodology allows successful investigations to be conducted in-house whilst providing the necessary flexibility to be tailored to distribution systems of varying sizes and sophistication. This is in accordance with previous research which has demonstrated that sustainability performance, especially relating to environmental sustainability can be enhanced through the use of a Six Sigma methodology (Calia et al., 2009; Habidin and Yusof, 2012; Zhang and Awasthi, 2014). Due to the rigorous and disciplined nature of Six Sigma methodologies (Garza-Reyes, 2015) it is not certain if the ease of implementation could have been enhanced through the use of simpler frameworks such as Lean (Ng et al., 2015). In this case, application of the Six Sigma framework achieved a 39\% reduction in annual water consumption, however it is not clear if this could have been enhanced through the utilisation of other frameworks was designed to overcome the shortfalls of Six Sigma. Green Lean Six Sigma (GL2S) and was shown on average to produce reductions in resource consumption by $20 \%$ to $40 \%$ (Cherrafi et al., 2016 b) which is similar to the $39 \%$ reduction witnessed in this case study however due to the inherent differences in the sectors and organisations in which this was applied a further casestudy on MPC would have to be conducted in order to determine if GL2S provide significant benefits of Six Sigma.

The design and installation of more sophisticated systems will allow for the quick and accurate capture of flow data and has the potential to greatly aid in reducing water consumption. The installation of telemetry systems at a DMA and household level will provide more accurate information on consumption, as well as real time consumption data in a water distribution system, making it possible to identify leaks or inefficient water consumption (Loureiro, 2010). Increased metering would improve the resolution of the leak detection process, reducing the amount of time spend locating leaks or inefficiencies in the system. In addition to metering, various sensing technologies such as IR thermographic imaging could be used (Hawari et al, 2017) as well as considering the operating pressure of the distribution network. It has been recognized that leakage rates increase with internal water pressure (Wu et al, 2010) and that considering pressure driven leakage in the design stage of the network can reduce overall leaks (Gupta et al, 2016). Considering the analytical nature of the six sigma framework, the collection of operational pressure data from the distribution network could be used to identify the areas in which leaks are most likely to occur and thus be used to further reduce site water consumption.

As technological strategies can be costly and would require a detailed cost benefit analysis before any capital works is undertaken: greater benefits are typically achieved by the fitting of efficient fixtures and appliances (Stewart et al., 2010). It has also been documented that high tech equipment and water efficient devices alone do not necessarily provide water savings (Geller et al, 1983), as end users must have an appreciation of the functions of the devices and apply them in the correct manner (Elizondo and Lofthouse, 2010). Additionally if these fittings are incorrectly fitted then there is the potential that large volumes of water could 
be wasted especially in public buildings (Roccaro et al., 2011). Both of these issues were apparent within the case study and related to urinal flow control devices which were wasting 2-4 litres a minute. This was a combination of faulty devices, incorrectly fitted devices, and cleaning staff increasing the flush frequency to reduce the amount of cleaning required. Rectification of this issue was tackled through in house training on how the fittings worked, how they should be positioned, and how to spot if they are working correctly. This has led to water savings of up to $90 \%$ in some facilities.

The behavioural aspects to water reduction have been shown to play an important part in achieving water savings. Lau (2012) demonstrated how the promotion of knowledge and awareness could yield significant water savings in high density housing in Hong Kong. The effectiveness of a similar strategy when applied to a single MOD estate would be questionable due to the high transient population with no visibility of personal water consumption (Randolph and Troy, 2008). This is particularly relevant on this site where the consumption patterns of domestic and non-domestic water consumption is still not fully understood. If targeted at an organisational level so that water conservation was embedded in to the military culture and institutionalised, then there is the potential to realise large water savings across all estates (Randolph and Troy, 2008).

\section{Conclusion}

- Six Sigma methodology can been successfully utilised to reduced water loss in a Private Water Supply Setting to meet environmental quality targets.

- The underlying principals were successfully applied to both supply side (leakage) and demand side (water efficiency audits) to achieve a 39\% reduction in annual consumption.

- The adoption of a systematic approach to reducing water consumption can aid in providing an effective, low cost solution even on sites with limited technology. As water conservation begins to play a more influential role within organisations, industry will naturally have to adapt to support these new requirements.

\section{Acknowledgement}

The support of Interserve, Defence Infrastructure Organisation and the Ministry of Defence.

\section{References}

Affinity Water. (2010). Water Efficiency Audit Guide. [Online] Available: https://www.affinitywater.co.uk/docs/business-water-audit-guide.pdf (January 2, 2017)

Antony, A. (2007). Six Sigma in service organisations. Benefits challenges and difficulties, common myths, empirical observations and success factors. International Journal of Quality and Reliability Management, 24, 294-311. https://doi.org/10.1108/02656710710730889

AWWA Water Loss Control Committee. (2003). Applying worldwide BMPs in water loss control. Journal of AWWA, 95, 65-79.

Banawi, A., \& Bilec, M. M. (2014). A Framework to Improve Construction Processes: Integrating Lean, Green and Six Sigma. International Journal of Construction Management, 
14, 45-55. https://doi.org/10.1080/15623599.2013.875266

Basu, R. (2004). Implementing Quality: A practical Guide to Tools and Techniques: Enabling the Power of operational excellence, Thomson Learning, London.

Bates, B. C., Kundzewicz, Z. W., Wu, S., \& Palutikof, J. P. (2008). Climate Change and Water-IPCC Technical Paper VI. Intergovernmental Panel on Climate Change Secretariat, Geneva.

British Institute of Facilities Management. (2007). Survey shows key role for FMs business continuity and sustainability. [Online] Available: www.bifm.org.uk/bifm/news/3899 (January $2,2017)$

Brooks, D. B. (2006). An operational definition of water demand management. International Journal of Water Resource Development, 22, 521-528.

https://doi.org/10.1080/07900620600779699

Cairns, R., Sharp, E., Maher, K., \& Jefferson, B. (2012). Scope for potential energy savings in the flocculation process. Water and Environment Journal, 26, 319-323.

https://doi.org/10.1111/j.1747-6593.2011.00291.x

Calia, R. C., Muller-Guerrini, F., \& de Castro, M. (2009). The impact of Six Sigma in the performance of a Pollution Prevention program. Journal of Clean Production, 17, 1303-1310. https://doi.org/10.1016/j.jclepro.2009.05.001

Cherrafi, A., Elfezazi, S., Chiarini, A., Mokhlis, A., \& Benhida, K. (2016a). The integration of lean manufacturing, Six Sig and Sustainability: A literature review and future research directions for developing specific model. Journal of Cleaner Production, 139, 828-846. https://doi.org/10.1016/j.jclepro.2016.08.101

Cherrafi, A., Elfezazi, S., Govindan, K., Garza-Reyes, J. A., Benhida, K., \& Mokhlis, A. (2016b). A framework for the integration of Green and Lean Six Sigma for superior sustainability performance. International Journal of Production Research, 55, 1-35.

https://doi.org/10.1080/00207543.2016.1266406

Colombo, A. F., \& Karney, B. W. (2002). Energy and costs of leaks: towards a comprehensive picture. Journal of Water Resources Planning and Management, 128, 441-450.

https://doi.org/10.1061/(ASCE)0733-9496(2002)128:6(441)

Elmualim, A., Shockley, D., Valle, R., Ludlow, G., \& Shah, S. (2010). Barriers and commitment of facilities management profession to the sustainability agenda. Building and Environment, 45, 58-64. https://doi.org/10.1016/j.buildenv.2009.05.002

Environment Agency. (2012). Businesses urged to use water efficiency as a way to boost profits. [Online] Available, http://www.environment-agency.gov.uk/news/142885 (January 7 2017)

Elizondo, G. M., \& Lofthouse, V. (2010). Towards Sustainable use of water at home understanding how much where and why? Journal of Sustainable Development, 3, 3-10. 
https://doi.org/10.5539/jsd.v3n1p3

FM World. (2013). MOD seeks water saving measures in future deals. [Online] Available: http://www.fm-world.co.uk/news/fm-industry-news/mod-seeks-water-saving-measures-in-fut ure-deals/ (January 16 2017).

Gaza-Reyes, J. A. (2015). Green Lean and the need for Six Sigma. International Journal of Lean Six Sigma, 6, 226-248. https://doi.org/10.1108/IJLSS-04-2014-0010

Geller, E. S., Erickson, J. B., \& Buttram, B. A. (1983). Attempts to promote residential water conservation with educational behavioural and engineering strategies. Population and Environment, 6, 96-112. https://doi.org/10.1007/BF01362290

Gupta, R., Nair, A. G. R., \& Ormsbee, L. (2016). Leakage as Pressure-Driven Demand in Design of Water Distribution Networks. Journal of Water Resources Planning and Management, 142, 1-14. https://doi.org/10.1061/(asce)wr.1943-5452.0000629

Habidin, N. F., \& Yusof, S. M. (2012). Relationship between lean six sigma, environmental management systems and organizational performance in Malaysian automotive industry. International Journal of Automotive Technology, 13, 1119-1125.

https://doi.org/10.1007/s12239-012-0114-4

Hawari, A., Khader, M., Hirzallah, W., Zayed, T., \& Moselhi, O. (2017). Integrated sensing technologies for detection and location of leaks in water distribution networks. Water Science and Technology: Water Supply, 17. https://doi.org/10.2166/ws.2017.044

Inozu, B., Niccolai, M. J., Whitcomb, C. A., Mac Claren, B., Radovic, I., \& Bourg, D. (2006). New horizons for ship building process improvement. Journal of Ship Production, 22, 87-98.

Karim, M. R., Abbaszadegan, M., \& LeChevallier, M. (2003). Potential for pathogen intrusion during pressure transients. Journal of American Water Works Association, 95, 134-146.

Kingdom, B., Liemberger, R., \& Martin, P. (2006). The challenge of reducing non-revenue water (NRW) in developing countries: how the private sector can help; a look at performance-based service contracting. Water Supply Sanitation sector board discussion paper series, $8,8-12$

Lai, C. C. (1991). Unaccounted for water and the economics of leak detection. Water Supply, $9,1-8$.

Lau, S. S. Y., Yang, F., \& Ma, A. Y. W. (2012). Potable water savings in high density housing. Journal of Facilities Management, 10, 226-240. https://doi.org/10.1108/14725961211246027

Laureani, A., Antony, J., \& Douglas, A. (2009). Lean Six Sigma in a call centre: a case study. International Journal of Productivity and Performance Management, 59, 757-768. https://doi.org/10.1108/17410401011089454

Loureiro, D. (2010). Consumption analysis methodologies for the efficient management of water distribution systems, PhD Thesis, Universidade Técnica de Liboa, Lisbon, Portugal. 


\section{Macrothink}

Environmental Management and Sustainable Development

ISSN 2164-7682

2017, Vol. 6, No. 2

Morais, D. C., \& de Almedia, T. (2007). Group decision-making for leakage management strategy of water network. Resources, Conservation and Recycling, 52, 441-459.

https://doi.org/10.1016/j.resconrec.2007.06.008

Morrison, J. (2004). Managing Leakage by District Metered Areas: A Practical Approach. Water, 21(2), 45-46.

Ng, R., Low, J. S. C., \& Song, B. (2015). Integrating and implementing Lean and Green practices based on proposition of Carbon-Value efficiency metric. Journal of Cleaner Production, 95, 242-255. https://doi.org/10.1016/j.jclepro.2015.02.043

Oakland, J. S., \& Tanner, S. J. (2007). A new framework for managing change. The TQM Magazine, 19, 572-589. https://doi.org/10.1108/09544780710828421

Phen, L. S., \& Hui, M. S. (2004). Implementing and applying six sigma in construction Journal of Construction and Engineering Management., 130, 482-9.

https://doi.org/10.1061/(ASCE)0733-9364(2004)130:4(482)

Price, S., Pitt, M., \& Tucker, M. (2011). Implications of a sustainability policy for facilities management organisation. Facilities, 29, 391-410.

https://doi.org/10.1108/02632771111146314

Randolph, B., \& Troy, P. (2008). Attitudes to conservation and water consumption. Environmental Science and Policy, 11, 441-445. https://doi.org/10.1016/j.envsci.2008.03.003

Roccaro, P., Falciglia, P. P., \& Vagliasindi, F. G. (2011). Effectiveness of water saving devices and educational programs in urban buildings. Water Science and Technology, 63, 57-65. https://doi.org/10.2166/wst.2011.190

Stewart, R. A., Willis, R. M., Giurco, D., Panuwatwanich, K., \& Capati, G. (2010). Web based knowledge management system: linking smart metering to the future of urban water planning. Australian Planner, 47, 66-74. https://doi.org/10.1080/07293681003767769

Waterwise. (2012). Water- the facts: Why do we need to think about water [Online] Available: http://www.waterwise.org.uk/data/resources/25/Water_factsheet_2012.pdf (May 08 2017).

Zhang, M., \& Awasthi, A. (2014). Using Six Sigma to achieve sustainable manufacturing. Innovative Design and Manufacturing. Proceedings of the 2014 International Conference on innovative design and manufacturing, Montreal, August 13-15.

Willis, R. M., Stewart, R. A., Panuwatwanich, K., Williams, P. R., \& Hollingsworth. (2011). Quantifying the influence of environmental and water conservation attitudes on household end use water consumption. Journal of Environmental Management, 92, 1996-2009. https://doi.org/10.1016/j.jenvman.2011.03.023

Wu, Z. Y., Sage, P., \& Turtle, D. (2010). Pressure-dependent Leak Detection Model and its Application to a District Water System. Journal of Water Resources Planning and Management, 136, 116-128. https://doi.org/10.1061/(ASCE)0733-9496(2010)136:1(116) 


\section{Macrothink

\section{Glossary}

DMA: District Metered Area

DMAIC: Define, Measure, Analyse, Improve, Control

MNF: Minimum Night Flow

MOD: Ministry of Defence

MPC: Mount Pleasant Complex

SIPOC: Suppliers, Inputs, Processes, Outputs, Customers

WDM: Water Demand Management

\section{Copyright Disclaimer}

Copyright for this article is retained by the author(s), with first publication rights granted to the journal.

This is an open-access article distributed under the terms and conditions of the Creative Commons Attribution license (http://creativecommons.org/licenses/by/3.0/). 